\title{
Financial Ratios And Stock Prices: Consistency Or Discrepancy? Longitudinal Comparison Between UAE And USA
}

Viviane Y. Naïmy, (Email: vnaimy@ndu.edu.lb), Notre Dame University, Lebanon

\begin{abstract}
This paper aims at studying the association between stock prices and relevant financial ratios, and comparing the results for Dubai and USA based-stocks. It is noticed that the relationship between Dubai stock prices and respective ratios is not significant, whereas a better correlation is observed for US stocks. Several models and tests are applied and more than forty regressions are built in order to do individual companies' assessment, sectors evaluation and countries comparison between USA and UAE.
\end{abstract}

\section{Introduction}

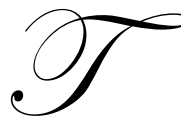

he United Arab Emirates stock market is relatively new and very small when compared to other developed markets. The official market started in 2000 and represented two governmental stock markets, Dubai and Abu Dhabi, under the supervision of the Emirates Securities and Commodities Authority. There is also an OTC market that works through several brokerage firms with most of them affiliated to the banking industry.

The Dubai Financial Market (DFM) was officially founded in March 2000 as the first organized stock market in Dubai. DFM has been trying to increase the investment alternatives available to investors and to facilitate and diversify sources of financing to the firms located in Dubai. The Dubai Financial Market includes about thirty five listed stocks, out of which only twenty can be considered as being actively traded. The breadth and depth of industries is also limited - most of the listed stocks are in the banking and insurance sectors, with the remaining stocks being in a wide range of real estate and other services related sectors.

The phenomenal growth in the Dubai Financial Market in 2004 and most of 2005 seems to be justified with high liquidity ${ }^{1}$ combined with an overly enthusiastic market sentiment. Many of the stocks traded in DFM are selling at prices that are extremely overpriced ${ }^{2}$. Practically, the market has become one driven by momentum with no consideration to the fundamentals of stock analysis ${ }^{3}$.

Investors may have learnt a lesson from the Black Tuesday ${ }^{4}$ for Dubai Financial Market, where the Dubai Market Index went down by around $12 \%$ in one day, buoyed by low liquidity and negative market sentiment. Stock analysts have been expecting such an event as inevitable given the overvaluation of the listed stocks.

\footnotetext{
${ }^{1}$ Partially due to the increase in oil prices.

${ }^{2}$ Where some normal-growth companies have very high and illogical P/E ratios.

${ }^{3}$ An example would be of how the market chose to read Emaar (one of the largest real estate company in the world) Properties' rights issuance in 2005 as positive signal for the share price. People have been blindly buying because they believe that the economic situation in Dubai is so good that any investment must succeed.

${ }^{4}$ In February 2006
} 
The objective of this paper is to analyze how the financial performance of some selected listed firms in the UAE and in the US is affecting their stock prices. This performance is measured by certain relevant financial ratios such as asset management, debt management, and profitability ratios. These ratios will be first measured individually and their tendency will be analyzed together with the one of their stock prices. In other terms, this paper aims at studying the effect that a combination of these ratios has on the price of the studied stock, and at identifying to what extent the price of the stock is dependent on the company's financial ratios. For this purpose, an overall between-country analysis, then a sector-breakdown analysis between countries, and an analysis for individual companies are carried out.

The first section describes the research design and the sampling process. The second section is devoted to an overall comparison between USA and Dubai selected listed stocks where hypothesis testing are made. The last section includes sectors breakdown and individual companies' assessment using time series analysis and more than forty regressions

\section{Sampling, Data Collection And Cleansing, Ratio Calculation, And Variables Distribution Analysis}

\section{I.1. Sampling}

\section{I.1.1. Dubai Stocks}

Only thirty five firms are listed in the Dubai Financial Market which makes the sampling easier to set and very close to the population and leads to representative results. However, the presence of one or two stocks which are markedly different from the others in terms of capitalization and quantity traded may cause a huge variation in the final results. The listed firms ${ }^{5}$ in the Dubai Financial Market are mainly divided up into three industries: Banking (7 stocks), Insurance (10 stocks), and Real Estate and Related Financing (5 stocks). The remaining stocks in this market fall into a variety of sectors, with most stocks being the single stock in that sector. Due to this lack of sector representation, we have chosen only sectors in which there is variety of companies in order to be able to detect trends and tendencies. For this reason, the chosen listed firms ${ }^{6}$ belong to the banking, insurance and real estate sectors. We are aware of the relatively small size of our sample; however, we believe that the selected firms are able to answer few of our inquiries. Table 1 lists the firms that have been included in this research.

Table 1: The Listed firms included in the sample for the DFM analysis

\begin{tabular}{|c|c|c|}
\hline Banking & Insurance & Real Estate \\
\hline 1. Commercial Bank of Dubai & 1. Arab Insurance Group & 1. Emaar Properties \\
\hline 2. Dubai Islamic Bank & Dubai Insurance & Union Properties \\
\hline 3. Emirates Bank International & 3. Dubai National Insurance & 3. Amlak Finance (Real Estate \\
\hline 4. Mashreqbank & 4. Dubai Islamic Insurance \& & related financing) \\
\hline 5. National Bank of Dubai & Reinsurance (AMAN) & \\
\hline & Islamic Arab Insurance Company & \\
\hline & 6. National General Insurance & \\
\hline & 7. Oman Insurance Company & \\
\hline
\end{tabular}

For the above stocks, year-end ratios and prices $^{7}$ have been collected and calculated for the period 20012005. Quarterly information has been also considered for a better representation.

\footnotetext{
${ }^{5}$ It was quite difficult to find detailed historical information for all companies due to the lack of public documentation.

${ }^{6}$ Within these industries, we have included all those stocks on which it was possible to obtain the required financial information.

${ }^{7}$ Some companies started trading on DFM only in the past 1 or 2 years consequently, few observations might not match the above mentioned period.
} 


\section{I.1.2. USA Stocks}

For comparison purpose between the Dubai and US stocks, US firms have been chosen from the same sectors as the ones for Dubai stocks. Based on high market capitalization and comparatively good financial performance in the past 5 years, the following US stocks were chosen to be used in this study.

Table 2: The Listed firms included in the sample for the US financial market analysis

\begin{tabular}{|c|c|c|}
\hline Banking & Insurance & Real Estate \\
\hline 1. Bank of America Corp & 1. $\quad$ MetLife, Inc. & 1. $\quad$ St. Joe Company \\
\hline 2. JP Morgan Chase And Co & 2. The Allstate Corporation & 2. Thomas Properties Group \\
\hline Wells Fargo \& Company & Prudential Financial & Bluegreen Corporation \\
\hline Wachovia Corp. & Hartford Financial & 4. California Costal Communities, \\
\hline Washington Mutual, Inc. & 5. Loews Corporation & Inc. \\
\hline Us Bancorp & 6. The Progressive Corp & 5. Consolidated Tomoka Land Co. \\
\hline National City Corporation & & Stratus Properties \\
\hline
\end{tabular}

\section{I.2. Data Collection And Ratio Calculation}

Most of the financial ratios are obtained from the financial statements of the studied company. Our main sources of information were Reuters and Dubai Financial Market for historical market prices in addition to individual websites for many Dubai-based companies. validity.

Data cleansing procedures mainly included comparing statements obtained from different sources to clarify

In most cases, data observed from different sources gave coherent figures. However, further research was performed in order to solve conflicts in information and clarify which source was most reliable.

A total of seven ratios ${ }^{8}$ have been taken into consideration. Some ratios were readily calculated such as Debt Ratio, Return on Equity, and Return on Total Assets. Three other ratios deemed important and were calculated separately. These ratios are: Total Assets turnover ${ }^{9}$, Profit Margin on Sales ${ }^{10}$, and Basic Earnings Power ${ }^{11}$.

\section{I.3. Variables Distribution Analysis}

The purpose of this section is to detect the best possible distribution that the data follows using the BestFit ${ }^{12}$ program where we compare the histogram of the data with the theoretical probability distributions available and see which gives the best fit. Table 3 provides the Chi-Square measure of the goodness of fit, the larger the test value is, the worse the fit is. These distributions are based on some ratios for the 19 selected companies in the US for the year $2005^{13}$. As for Dubai companies, the randomly selected year is 2002 .

\footnotetext{
${ }^{8}$ Some other ratios would have been useful to include in our study such as the fixed assets turnover and the Times Interest Earned ratios, but the available financial statements were consolidated and individual values for fixed assets and interest expenses could not be obtained or deduced.

${ }^{9}$ Sales/total assets

${ }^{10} \mathrm{Net}$ income available to common stockholders/sales

${ }^{11}$ EBIT / Total Assets

${ }^{12}$ Which is a statistical package developed by Palisade Decision Tools, 2006.

${ }^{13}$ This year was chosen randomly. Distributions for other years are not presented in this paper because of huge number of variables and graphs.
} 
Table 3: Test Values for USA and Dubai variables

\begin{tabular}{|c|c|c|}
\hline$\underline{\text { USA }}$ & Chi-Square & Best Fit Probability Distribution \\
\hline Debt Ratio & 4.22 & Normal \\
\hline Return On Equity & 1.11 & InvGauss \\
\hline Return On Assets & 2.44 & Pareto \\
\hline Total Assets Turnover & 2.00 & Normal \\
\hline Profit Margin & 2.88 & Pareto \\
\hline Basic Earnings Power & 0.22 & Normal \\
\hline Dubai & & Normal \\
\hline Debt Ratio & 0 & Normal \\
\hline Return On Equity & 3 & Exponential \\
\hline Return On Assets & 1.33 & Normal \\
\hline Total Assets Turnover & 0.33 & LogLogistic \\
\hline Profit Margin & 0.33 & 1.33 \\
\hline
\end{tabular}

Most of the variables follow a normal distribution. Consequently we can continue our modeling with the assumption of having normal distributions. However, in the regression analysis, exponential distributions may be considered in certain cases.

\section{Stock Prices' Elasticity Toward Ratios Variation: An Overall Comparison Between Usa And Dubai}

In this section we compare the effect of ratios' changes on stock prices for USA and Dubai stocks. To this end, we have measured the annual percentage change of the eight studied variables ${ }^{14}$ in each country and for each company individually. Then the average annual values of each ratio corresponding to each studied firm in both countries have been carefully calculated ${ }^{15}$. The following equation illustrates the calculation's methodology.

$\overline{R_{i D}} \approx \sum_{t=1}^{15}\left(A_{D} \times R_{i t}\right) \div 15$

Where:

$R_{i D}$ is the average selected ratio for Dubai market

$A_{D}$ is the adjustment factor

$R_{i t}$ is the value of each firm's selected ratio

As for the US market the same formula has been applied ${ }^{16}$ for the sample constituted of 19 firms instead of 15 and of course with a different adjustment factor. Table 4 summarizes the scatterplots output for prices ${ }^{17}$ versus each variable.

\footnotetext{
${ }^{14}$ Stock Price and the seven selected ratios. has been used to avoid insignificant sharp changes.

${ }_{16} \overline{R_{i U S}} \approx \sum_{t=1}^{19}\left(A_{U S} \times R_{i t}\right) \div 19$

${ }^{17}$ Same formula is applied to calculate the adjusted average price
}

${ }^{15}$ An adjustment factor that takes into consideration the size of each firm included in the sample (in terms of equity shareholders) 
Table 4: Correlation Table Between Prices and Ratios

a. Dubai Market

\begin{tabular}{|c|c|c|c|c|c|c|c|}
\hline$\overline{R_{i D}}$ & $\begin{array}{c}\text { Liabilities/E } \\
\text { quity }\end{array}$ & Debt ratio & ROE & ROA & $\begin{array}{c}\text { Total Assets } \\
\text { turnover }\end{array}$ & $\begin{array}{c}\text { Profit } \\
\text { margin on } \\
\text { sales }\end{array}$ & $\begin{array}{c}\text { Basic } \\
\text { Earnings } \\
\text { Power }\end{array}$ \\
\hline$\rho_{R_{i d}}, P$ & -0.529 & -0.591 & 0.598 & 0.841 & -0.275 & 0.997 & 1.000 \\
\hline
\end{tabular}

b. US Market

\begin{tabular}{|c|c|c|c|c|c|c|c|}
\hline$\overline{R_{i U S}}$ & $\begin{array}{c}\text { Liabilities/E } \\
\text { quity }\end{array}$ & Debt ratio & ROE & ROA & $\begin{array}{c}\text { Total Assets } \\
\text { turnover }\end{array}$ & $\begin{array}{c}\text { Profit } \\
\text { margin on } \\
\text { sales }\end{array}$ & $\begin{array}{c}\text { Basic } \\
\text { Earnings } \\
\text { Power }\end{array}$ \\
\hline$\rho_{R_{i U S}}, P$ & 0.892 & 0.586 & -0.593 & -0.598 & -0.921 & -0.722 & -0.025 \\
\hline
\end{tabular}

Too much emphasis cannot be given to the above figures despite the presence of a couple of high correlation. In order to check if market price and the ratio under consideration are independent of each other or not, we shall do hypothesis testing.

\section{Hypothesis Testing}

We will use a two-sample t-test for the difference between means of different variables to see whether the two variables being tested are independent or not.

Null hypothesis (H0): Price and the selected ratio are independent of each other.

Alternative Hypothesis (Ha): There is dependence between price and that ratio.

Under Hypothesis Testing in the statistical inference, two-sample analysis is chosen, with null hypothesis value being 0 and alternative hypothesis being "not equal to null value". It is a two-tailed test because results in either positive or negative direction can lead to rejection of the null-hypothesis. Table 6 recapitulates the results of the hypothesis test for all the selected ratios in both markets.

One detailed example is illustrated in table 5, where the independence/dependence between price of USA stock and the debt ratio is tested. 
Table 5: Hypothesis testing for Difference between population means for US Stock Price \& Total liability/Equity

\begin{tabular}{|lcc|} 
& Price & Total Liabilities/Equity \\
Unequal \\
Hypothesis Test (Difference of Means) & Equal & Variances \\
\hline \hline Hypothesized Mean Difference & Variances & 0 \\
Alternative Hypothesis & 0 & $<>0$ \\
Sample Mean Difference & $<>$ & 0.2403 \\
Standard Error of Difference & 0.2403 & 0.0774 \\
t-Test Statistic & 0.0774 & 3.1017 \\
p-Value & 3.1017 & 0.0532 \\
Null Hypoth. at 10\% Significance & 0.0211 & Reject \\
Null Hypoth. at 5\% Significance & Reject & Don't Reject \\
Null Hypoth. at 1\% Significance & Reject & Don't Reject \\
Equality of Variances Test ${ }^{18}$ & Don't Reject & \\
\hline \hline Ratio of Sample Variances & & \\
p-Value & & \\
\hline
\end{tabular}

Table 6: Summary of the results from hypothesis testing for price versus different variables

a. Hypothesis Testing Results for US Stocks

\begin{tabular}{|c|c|}
\hline Liability/Equity & Reject null hypothesis (at 10\% significance level) \\
\hline Debt ratio & Reject null hypothesis (at 10\% significance level) \\
\hline ROE & Don't reject null hypothesis \\
\hline ROA & Don't reject null hypothesis \\
\hline Total Assets Turnover & Reject null hypothesis (at 5\% and 10\% significance levels) \\
\hline Profit Margin on Sales & Don't reject null hypothesis \\
\hline Basic Earnings Power & Don't reject null hypothesis \\
\hline
\end{tabular}

\section{b. $\quad$ Hypothesis Testing Results for Dubai Stocks}

\begin{tabular}{|c|l|}
\hline Liability/Equity & Don't reject null hypothesis \\
\hline Debt ratio & Don't reject null hypothesis \\
\hline ROE & Don't reject null hypothesis \\
\hline ROA & Don't reject null hypothesis \\
\hline Total Assets Turnover & Don't reject null hypothesis \\
\hline Profit Margin on Sales & Don't reject null hypothesis \\
\hline Basic Earnings Power & Don't reject null hypothesis \\
\hline
\end{tabular}

According to the above results, we can see that dependence between price and ratios seems to be frequent for some ratios in the US market. However for Dubai stocks, price does not seem to be dependant on any of the given ratios. Although these initial results are somewhat indicative of expected results, we need to further deepen our analysis in order to confirm the pertinence of these results. Therefore, in the next section, we shall study each sector in each country separately.

\footnotetext{
${ }^{18}$ For the equality of variance test, since the p-value is quite small (within the $95 \%$ significance level), we look at the column of unequal variances. Looking at the t-test statistic of 3.10 and p-value of 0.0532 , there is enough evidence to reject the null hypothesis at the $10 \%$ confidence level (since $0.053 \%<10 \%$ ). However, at the $1 \%$ and $5 \%$ significance level, we cannot reject the null hypothesis. Therefore, the relationship between price and Liability to Equity is not strongly confirmed.
} 


\section{Sectors' Assessment: Longitudinal Comparison Between USA And Dubai Markets' Reaction To Financial Performance}

In this section, all the companies are broken down into their respective sectors in order to draw sectors comparison between USA and Dubai. This comparison is expected to accurately narrow down results. Times series graphs were attempted for each variable along with price. For simplicity, we created single time-series graphs with only those variables which had some similarity in movement with price. Below is the time series ${ }^{19}$ of the Dubai banking sector ${ }^{20}$ for illustration purpose.

Figure 1: The Dubai Banking Sector's Performance

\section{Time Series}
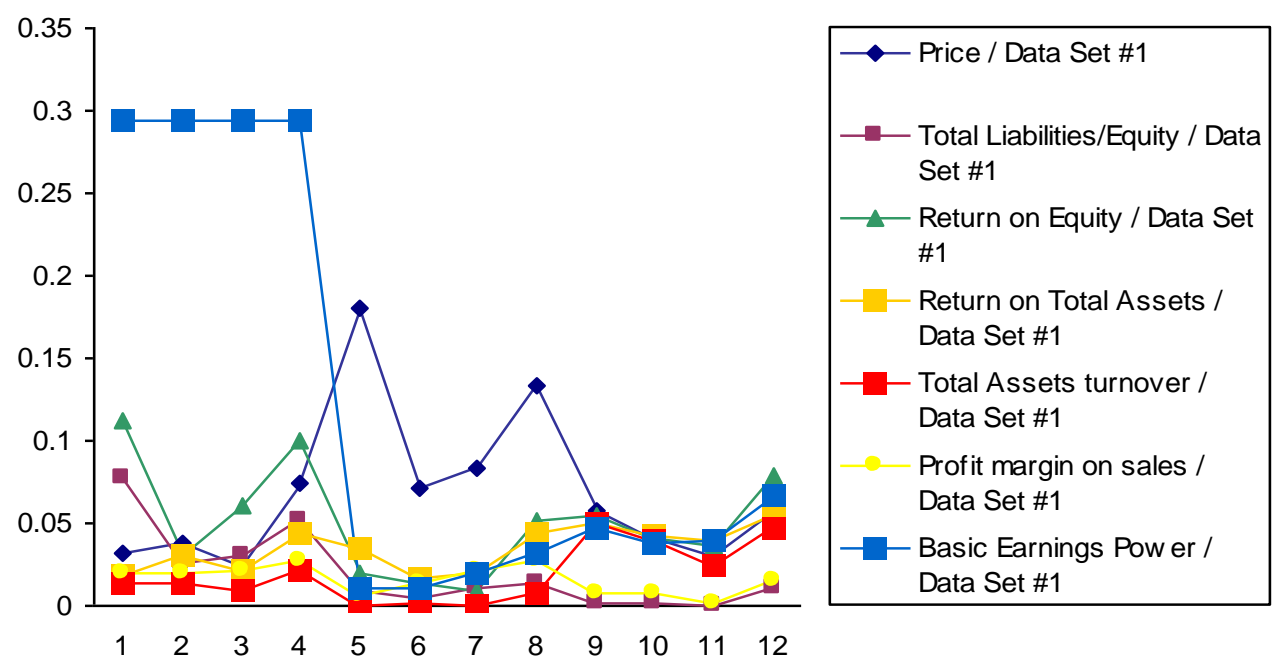

In the above graph, some relationship between the movement in price and the other selected ratios is clearly depicted. However, this doesn't seem statistically significant. Therefore, correlation and regression analysis are conducted per sector and per country. Table 7 summarizes the correlation coefficient between the price and ratios per sector and per country.

Table 7: Correlation comparison per sector and per country

\begin{tabular}{|c|c|c|c|c|c|c|}
\hline \multirow{2}{*}{$\rho_{R_{i}, P}$} & \multicolumn{2}{|c|}{ Banking Sector } & \multicolumn{2}{|c|}{ Insurance } & \multicolumn{2}{|c|}{ Real Estate } \\
\hline & US & Dubai & US & Dubai & US & Dubai \\
\hline Total Liabilities/Equity & 0.031 & -0.434 & 0.958 & -0.541 & 0.931 & -0.741 \\
\hline Debt ratio & -0.033 & -0.422 & 0.366 & -0.527 & 0.846 & -0.704 \\
\hline Return on Equity & 0.426 & -0.919 & -0.789 & 0.445 & -0.226 & 0.781 \\
\hline Return on Total Assets & 0.582 & -0.569 & -0.781 & 0.676 & -0.212 & 0.998 \\
\hline Total Assets turnover & 0.165 & -0.712 & -0.949 & -0.502 & -0.591 & -0.953 \\
\hline Profit margin on sales & 0.563 & 0.121 & -0.676 & 0.952 & -0.249 & 0.979 \\
\hline Basic Earnings Power & 0.519 & -0.912 & 0.401 & 0.981 & -0.221 & 0.869 \\
\hline
\end{tabular}

\footnotetext{
${ }^{19}$ In order not to clutter up this paper, we will only illustrate the time series graph represented in figure 1.

${ }^{20}$ Quarterly changes have been measured, so that the cumulative changes represent the percentage change related to the studied year with respect to the previous one.
} 
Six regressions ${ }^{21}$ are also built for each sector in each country in order to trace any possible explanation for the price variability as a response to changes in the financial ratios of the sector under consideration ${ }^{22}$. Table 8 recaps the main parameters of these regressions and gives a quick conclusion corresponding to each equation.

Table 8: Recapitulation of the sectors' regressions in the US and in Dubai

\begin{tabular}{|c|c|c|c|}
\hline & & $\begin{array}{c}\text { Regression Equation } \\
\end{array}$ & Interpretation \\
\hline \multirow[t]{2}{*}{$\begin{array}{l}\text { Banking } \\
\text { Sector }\end{array}$} & US & $\begin{array}{l}\Delta^{23} \text { Price }=0.02614+11.9533 \Delta \text { Debt Ratio }+0.31859 \Delta \mathrm{ROE} \\
\text { Multiple R: } 0.6512 \text { R-Square: } 0.4241 \text { p-value: } 0.7589\end{array}$ & $\begin{array}{l}\text { There does not seem to be a } \\
\text { significant relationship between } \\
\text { price and ratios. }\end{array}$ \\
\hline & Dubai $^{24}$ & $\begin{array}{c}\Delta \text { Price }=0.3351-0.7819 \Delta \text { Total Liabilities/Equity } \\
\text { Multiple R: } 0.4342 \text { R-Square: } 0.1885 \text { p-value: } 0.7141\end{array}$ & $\begin{array}{l}\text { Complete absence of } \\
\text { relationship. }\end{array}$ \\
\hline \multirow[t]{2}{*}{ Insurance } & $\mathrm{US}^{25}$ & $\begin{array}{c}\Delta \text { Price }=0.1081-3.1192 \Delta \text { Total Assets Turnover } \\
\text { Multiple R: } 0.9488 \text { R-Square: } 0.9001 \text { p-value: } 0.0512\end{array}$ & $\begin{array}{l}\text { There is a strong relationship } \\
\text { between price and ratios. }\end{array}$ \\
\hline & Dubai & $\begin{array}{c}\Delta \text { Price }=1.3124+3.2844 \Delta \text { Debt Ratio }-5.4756 \Delta \text { Total Assets } \\
\text { Turnover } \\
\text { Multiple R: } 0.9814 \text { R-Square: } 0.9631 \text { p-value: } 0.1231\end{array}$ & $\begin{array}{l}\text { The explanatory variable does } \\
\text { not account for the variability in } \\
\text { price }^{26} \text {. }\end{array}$ \\
\hline \multirow[t]{2}{*}{$\begin{array}{l}\text { Real } \\
\text { Estate }\end{array}$} & US & $\begin{array}{c}\Delta \text { Price }=0.2452+0.0480 \Delta \text { Basic Earnings Power } \\
\text { Multiple R: } 0.9892 \text { R-Square: } 0.9785 \text { p-value: } 0.1466\end{array}$ & $\begin{array}{l}\text { Shy relationship between price } \\
\text { and ratios due to the high p- } \\
\text { value. }\end{array}$ \\
\hline & Dubai & $\begin{array}{c}\Delta \text { Price }=0.2693+1.0618 \Delta \text { ROA } \\
\text { Multiple R: } 0.9983 \text { R-Square: } 0.9965 \text { p-value: } 0.0376\end{array}$ & $\begin{array}{l}\text { The variability of price can be } \\
\text { explained up to an acceptable } \\
\text { level by the change of } \mathrm{ROA}^{27} \text {. }\end{array}$ \\
\hline
\end{tabular}

Although the above results are statistically confirmed by the $\mathrm{F}$ and $\mathrm{t}$ values, we are still using average values of percentage changes from period to period for a limited number of years which might affect the accuracy of the final conclusions. Therefore, we assessed all the firms included in the sample individually by conducting individual regressions to each company and by using actual values ${ }^{28}$. Variables with multicollinearity between explanatory variables have been highlighted ${ }^{29}$ and consequently redundant variables were excluded. Table 8 illustrates the output of this individual firms' analysis.

As shown in table 8, the number of entries under significant explanatory variables are higher for US companies compared to Dubai ones. This trend is obvious in both the insurance and real estate sectors, where almost all US firms have a strong relationship between stock prices and ratios, whereas in Dubai there are hardly few firms ${ }^{30}$ showing this relationship.

\footnotetext{
${ }^{21}$ In the regression analysis, average change of companies' prices in the banking sector is the dependant variable and average change of all the other variables are taken as the independent variables.

${ }^{22}$ Regressions construction are based on the variables distribution analysis done in the first section.

${ }^{23}$ where $\Delta$ stands for $\%$ change

${ }^{24}$ None of the variables in the time-series graph seemed to have any relation with market price.

${ }^{25}$ The variable which has been included in the regression equation -Total Assets Turnover- is multicollinear with profit margin on sales and total liabilities to equity.

${ }^{26} \mathrm{R}$-Square, is very high, however the p-values for both the F-ratio in the ANOVA table, and for the t-value in regression are very high, therefore, none of the explanatory variables can help to explain the variability in \% difference of price.

${ }^{27}$ Total Assets Turnover, Profit Margin on Sales, and Basic Earnings Power are multicollinear with ROA.

${ }^{28}$ For prices and ratios.

${ }^{29}$ Using correlation matrix.

${ }^{30}$ There are only two companies (Emirates Bank and National Bank of Dubai) in which we found more than two explanatory ratios.
} 
Table 8: Individual companies' analysis output

\begin{tabular}{|c|c|c|c|}
\hline Banking Sector & & & \\
\hline$\underline{\text { US Firms }}$ & Adjusted R Square & $\begin{array}{l}\text { p-value of } \\
\text { ANOVA }\end{array}$ & Significant explanatory variables $^{31}$ \\
\hline Bank of America Corp & $85.17 \%$ & 0.0163 & Total Assets Turnover \\
\hline JP Morgan Chase \& Co. & $91.84 \%$ & 0.0408 & $\begin{array}{c}\text { Debt Ratio, Total Liabilities/Equity, ROA, } \\
\text { Profit Margin on Sales, BEP }\end{array}$ \\
\hline US Bancorp & $63.51 \%$ & 0.0666 & ROE, ROA, Profit Margin on Sales, BEP \\
\hline Wells Fargo \& Co. & $-0.0703 \%$ & 0.6279 & - \\
\hline Washington Mutual Inc. & $73.33 \%$ & 0.0405 & ROE, ROA, Profit Margin on Sales, BEP \\
\hline \multicolumn{4}{|l|}{ Dubai Firms } \\
\hline Commercial Bank of Dubai & 0.9455 & 0.0183 & Total Liabilities/Equity, Debt Ratio \\
\hline Dubai Islamic Bank & $\begin{array}{l}\text { No variables entered } \\
\text { regression equation }\end{array}$ & - & ( \\
\hline Emirates Bank & $75.70 \%$ & 0.0846 & $\begin{array}{l}\text { Debt ratio, Liabilities/Equity, ROE, ROA, } \\
\text { Profit Margin on Sales, BEP }\end{array}$ \\
\hline Mashreqbank & $93.59 \%$ & 0.0216 & Debt Ratio \\
\hline National Bank of Dubai & $98.76 \%$ & 0.0643 & $\begin{array}{c}\text { Liabilities/Equity, Total Assets Turnover, Debt } \\
\text { Ratio }\end{array}$ \\
\hline
\end{tabular}

\begin{tabular}{|c|c|c|c|}
\hline \multicolumn{4}{|l|}{ Insurance Sector } \\
\hline \multicolumn{4}{|l|}{ US Firms } \\
\hline Hartford Financial & $69.60 \%$ & 0.0498 & Log(Total Assets Turnover) \\
\hline Loews Corporation & $50.03 \%$ & 0.1113 & - \\
\hline MetLife Inc. & $88.83 \%$ & 0.0106 & Total Assets Turnover \\
\hline The Progressive Corporation & $91.88 \%$ & 0.0065 & Debt Ratio, Total Liabilities/Equity \\
\hline Prudential Financial & $91.48 \%$ & 0.0070 & $\begin{array}{c}\text { Log(Total Liabilities/Equity), } \log (\text { Debt Ratio), } \\
\text { Log(ROE), } \log (\text { ROA), Log(Total Assets } \\
\text { Turnover), Log(Profit Margin on Sales), } \\
\text { Log(BEP) }\end{array}$ \\
\hline \multicolumn{4}{|l|}{ Dubai Firms } \\
\hline $\begin{array}{l}\text { Dubai Islamic Insurance and } \\
\text { Reinsurance(AMAN) }\end{array}$ & $86.29 \%$ & 0.1687 & - \\
\hline Arab insurance Group & $99.78 \%$ & 0.0273 & Total Liabilities/Equity, Debt Ratio \\
\hline Dubai insurance Company & $\begin{array}{l}\text { No variables entered } \\
\text { regression equation }\end{array}$ & - & 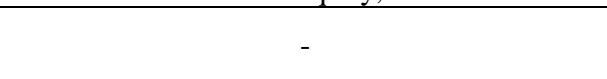 \\
\hline National General Insurance & $\begin{array}{l}\text { No variables entered } \\
\text { regression equation }\end{array}$ & - & - \\
\hline Oman Insurance Company & $95.36 \%$ & 0.1243 & ROE, Profit Margin on Sales \\
\hline
\end{tabular}

c. Real Estate Sector

\begin{tabular}{|c|c|c|c|}
\hline US Firms & & & \\
\hline Bluegreen Corporation & $97.83 \%$ & 0.0009 & $\begin{array}{l}\text { ROE, ROA, Total Assets Turnover, Profit } \\
\text { Margin on Sales, BEP }\end{array}$ \\
\hline $\begin{array}{l}\text { California Coastal Communities } \\
\text { Inc. }\end{array}$ & $85 \%$ & 0.0171 & Total Assets Turnover \\
\hline St.Joe Company & $92.50 \%$ & 0.0375 & Log(Debt Ratio), Log(Total Assets Turnover) \\
\hline Strauss Properties & $99.92 \%$ & 0.0184 & Total Assets Turnover, ROE \\
\hline Consolidated Tomoka Land Co. & $69.98 \%$ & 0.0488 & Log(Total Liabilities/Equity), Log(Debt Ratio) \\
\hline \multicolumn{4}{|l|}{ Dubai Firms } \\
\hline Emaar Properties & $\begin{array}{l}\text { No variables entered } \\
\text { regression equation }\end{array}$ & - & - \\
\hline Union Properties & $\begin{array}{l}\text { No variables entered } \\
\text { regression equation }\end{array}$ & - & - \\
\hline Amlak Finance ${ }^{32}$ & $93.87 \%$ & 0.0206 & Basic Earnings Power \\
\hline
\end{tabular}

${ }^{31}$ Redundant variables are also included.

${ }^{32}$ Real estate related. 


\section{Conclusion}

We were able to come out in this study with some interesting findings for local and international investors by showing a significant relationship between stock prices and financial ratios for US companies unlike the majority of firms located in Dubai. Thus, we can infer that US stock prices are indeed based on objective measures, in contrast with Dubai ones, where at least the objective measures considered in this paper does not seem to have any correlation with the market price. Dubai Stock Market seems to be one that is still driven by investors' sentiment and financial aspects are not considered by these investors. Most of the time, investing in this market appears as being function of pure speculation and unreasonable risk taking not justified nor supported by financial fundamentals.

\section{Bibliography}

1. Commercial Bank of Dubai http://www.cbd.co.ae

2. Dickey, D. A. and Fuller, W. A. (1979), Distributions of the Estimators for Autoregressive Time Series With a Unit Root, Journal of the American Statistical Association, 74, 427-31.

3. Dubai Financial Market New website http://www2.dfm.ae

4. Dubai Financial Market website http://www.dfm.ae

5. Dubai Islamic Insurance and Reinsurance http://www.aman.ae

6. Emirates Bank http://www.ebgannualreports.ae

7. InFinancials http://www.infinancials.com

8. Islamic Arab Insurance http://www.islamicarab.ae

9. Johansen, S. (1988), Statistical Analysis of Cointegrating Vectors, Journal of Economic Dynamics and Control, 12, 231-54.

10. Johansen, S. (1991), Estimation and Hypothesis Testing of Cointegration in Gaussian Vector Autoregressive Models, Econometrica, 59, 1551-80.

11. Mashreqbank http://www.mashreqbank.com

12. Naïmy V. (2003), Marchés émergents, financement des PME et croissance économique : étude du cas libanais NDU Press.

13. Naimy V. (2005), Measuring the Effect of Financial Liberalization On The Supply Of Credit To The Private Sector: The Case Of Lebanon. The International Business And Economics Research Journal, ISSN 1535-0754, Volume 4, Number 5, May 2005, p. 17-30.

14. Naimy V. (2006), Measuring, Adjusting, and Forecasting Beta: The Case of All the Lebanese Listed Firms, The Journal of Business \& Economics Research, Volume 4, Number 4, April 2006 p. 53-63

15. Naimy V. (2006), The Black-Scholes Model Guideline for Options Course as Taught at Notre Dame University- Lebanon, The Journal of Business \& Economics Research, Volume 4, Number 1, January 2006, p. 59-64

16. Naimy V. (2007), Independency or Correlation? The GCC Stock Markets, Interest Rates, and Oil Prices: Against All Financial Rules, The International Business And Economics Research Journal, Volume 6, Number 2, February 2007, p. 9-18.

17. National General Insurance http://www.ngi.ae

18. Reuters, https://3000xtra.glbl1.reuters.com

19. Sala-i-Martin, X. (1997), I just run two million regressions, AEA Papers and Proceedings, 87, 178-83.

20. www.finance.gov.lb

21. www.Mideastweb.com

22. www.state.gov

23. www.worldbank.com

24. Yahoo Finance http://finance.yahoo.com 